\title{
Identification of secondary binding sites on protein surfaces for rational elaboration of synthetic protein mimics
}

\author{
Justin M. Torner, Yuwei Yang, David Rooklin, Yingkai Zhang* and Paramjit S. Arora* \\ Department of Chemistry, New York University, 100 Washington Square East, New York, NY 10003 \\ Email: arora@nyu.edu or yingkai.zhang@nyu.edu
}

\section{Supporting Information}

$\begin{array}{lr}\text { Supporting Figures } & \text { S2 }\end{array}$

$\begin{array}{lr}\text { Scheme S1. Synthesis of } \mathrm{G}^{*} & \text { S2 }\end{array}$

Scheme S2. Solid phase synthesis of HBS peptides $\quad S 2$

Figure S1. Autodock Vina scores for side chain fragments docked into MdmX $2^{\circ}$ site $\quad$ S3

$\begin{array}{ll}\text { Figure S2. Peptide characterization } & \text { S3 }\end{array}$

Figure S3. Direct binding assay $\quad$ S4

Figure S4. Competitive binding assay $\quad$ S4

Figure S5. ${ }^{15} \mathrm{~N}-{ }^{1} \mathrm{H}$ HSQC NMR spectra of Mdm2

Figure S6. ${ }^{15} \mathrm{~N}-{ }^{1} \mathrm{H}$ HSQC NMR spectra of $\mathrm{MdmX} \quad S 6$

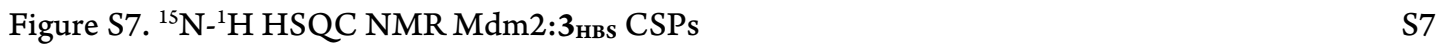

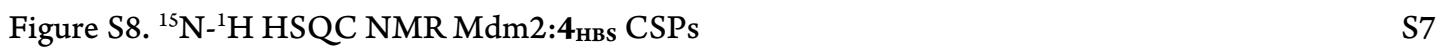

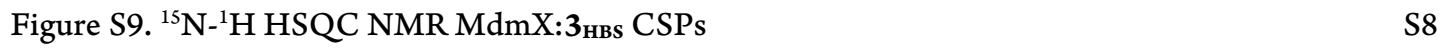

Figure S10. ${ }^{15} \mathrm{~N}-{ }^{1} \mathrm{H}$ HSQC NMR MdmX:4 ${ }_{\text {Hвs }}$ CSPs $\quad$ S8

$\begin{array}{lr}\text { Supporting Methods } & \text { S9 }\end{array}$

o-nosyl-N-allyl-glycine $\left(\mathrm{G}^{*}\right)$ synthesis $\quad$ S9

$\begin{array}{ll}\text { Peptide synthesis } & \text { S9 }\end{array}$

HBS peptide synthesis $\quad$ S9

$\begin{array}{lr}\text { Fluorescent probe synthesis } & \mathrm{S} 10\end{array}$

$\begin{array}{lr}\text { Protein expression and purification } & \text { S10 }\end{array}$

$\begin{array}{lr}\text { FP binding assay } & S 10\end{array}$

HSQC NMR $\quad S 11$

CD spectroscopy $\quad S 11$

$\begin{array}{lr}\text { AlphaSpace Analysis and Fragment Screening } & \text { S11 }\end{array}$

$\begin{array}{lr}\text { Supporting References } & \mathbf{S 1 2}\end{array}$ 


\section{Supporting Figures}<smiles>C=CCNS(=O)(=O)c1ccc(-c2ccc([N+](=O)[O-])c([N+](=O)[O-])c2)cc1S(=O)(=O)N(CC=C)S(=O)(=O)c1ccc(F)cc1[N+](=O)[O-]</smiles>

I

II

III

$\mathbf{G}^{*}$

Scheme S1 Synthesis of $\mathbf{G}^{*}$

FmocHN<smiles>[R]C(NC(=O)CN(CC)CC=C)C(=O)NOCC</smiles>

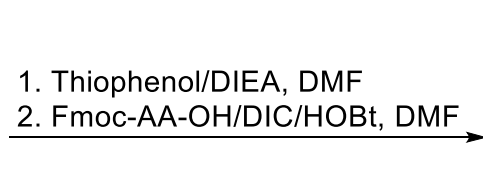<smiles>[R]C(NC(=O)CN(CC=C)C(=O)C([R])NC(F)F)C(=O)NCCO</smiles>

1. $20 \%$ Piperidine, DMF 2. FmOC-AA-OH/DIC/HOBt, DMF

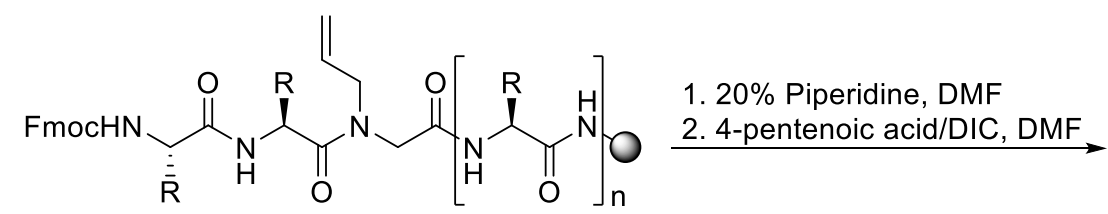

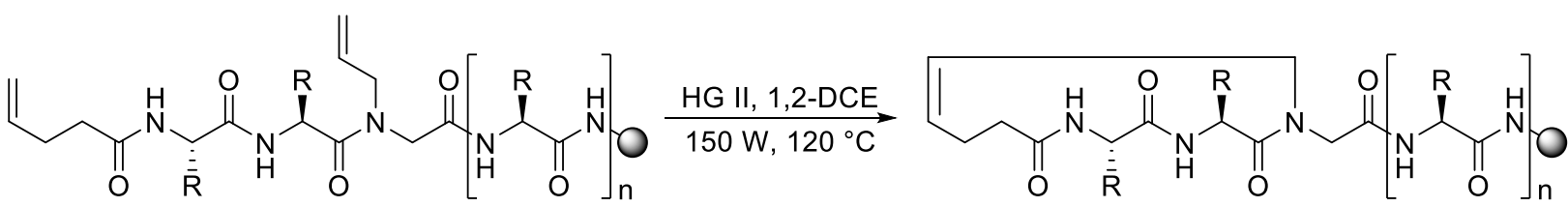

Scheme S2 Solid phase synthesis of HBS peptides 


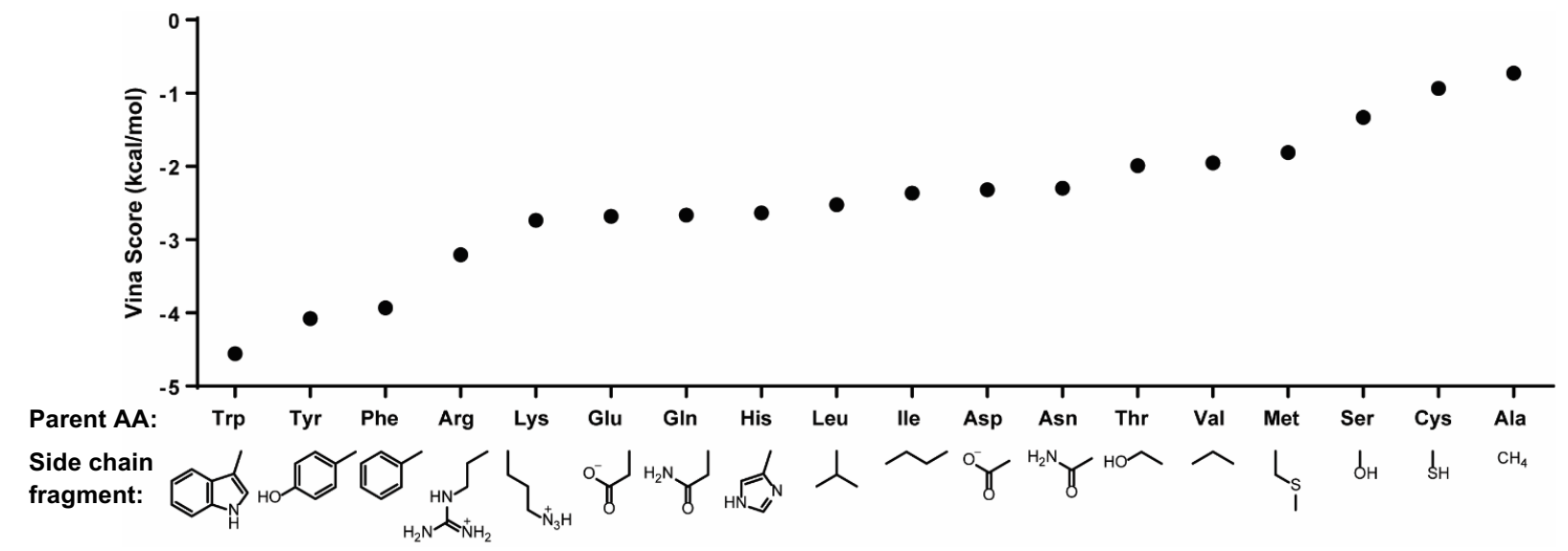

Figure S1 Autodock Vina scores of amino acid side chain fragments docked into the MdmX secondary binding site.
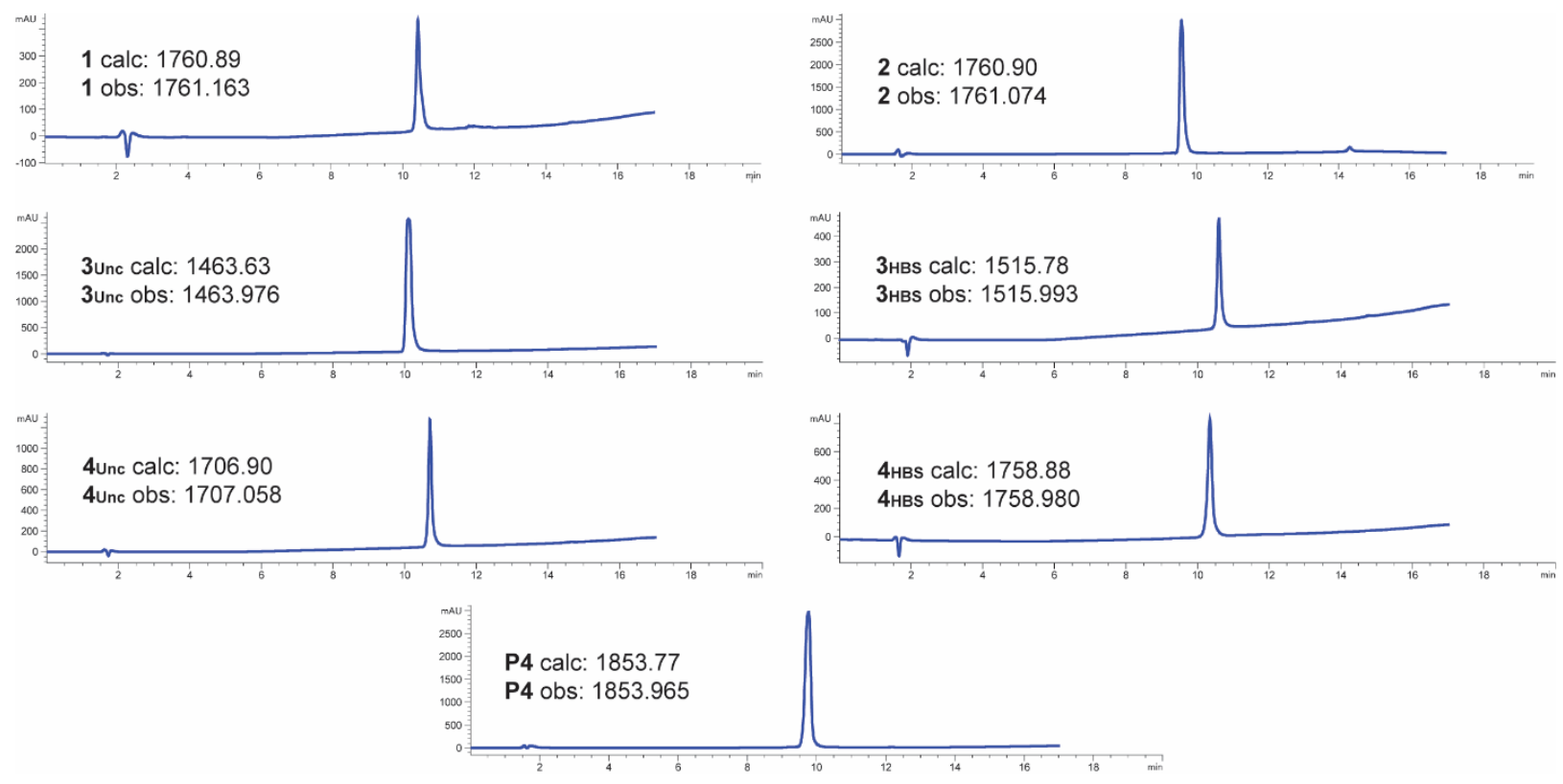

Figure S2 Peptide characterization. HPLC traces and MALDI-TOF $\mathrm{m} / \mathrm{z}$ data are shown. 

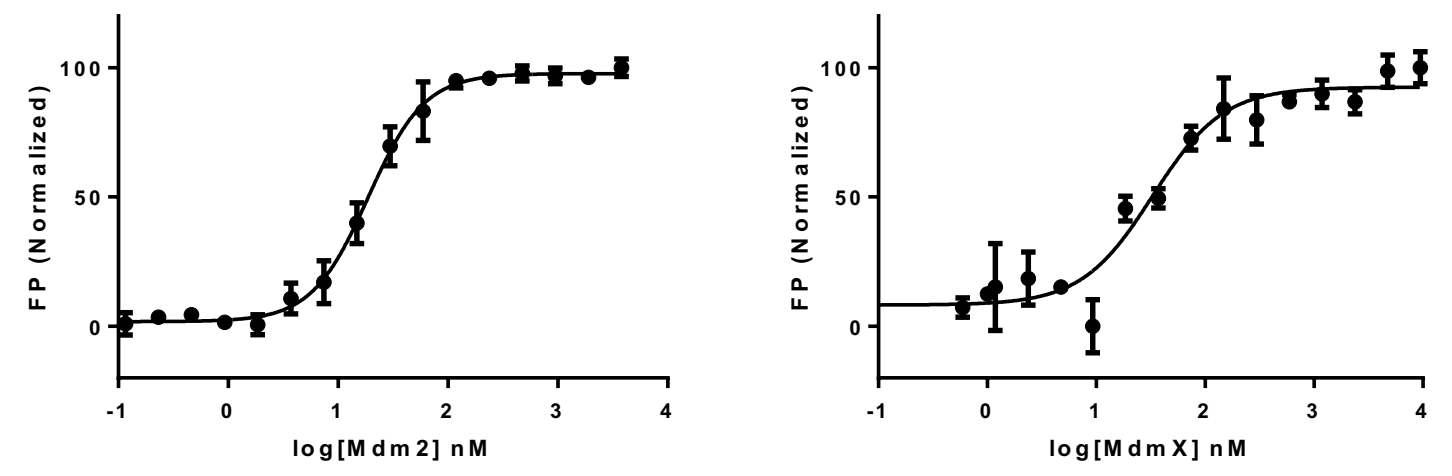

Figure S3 Direct binding of probe P4 to Mdm2 (left) and MdmX (right)
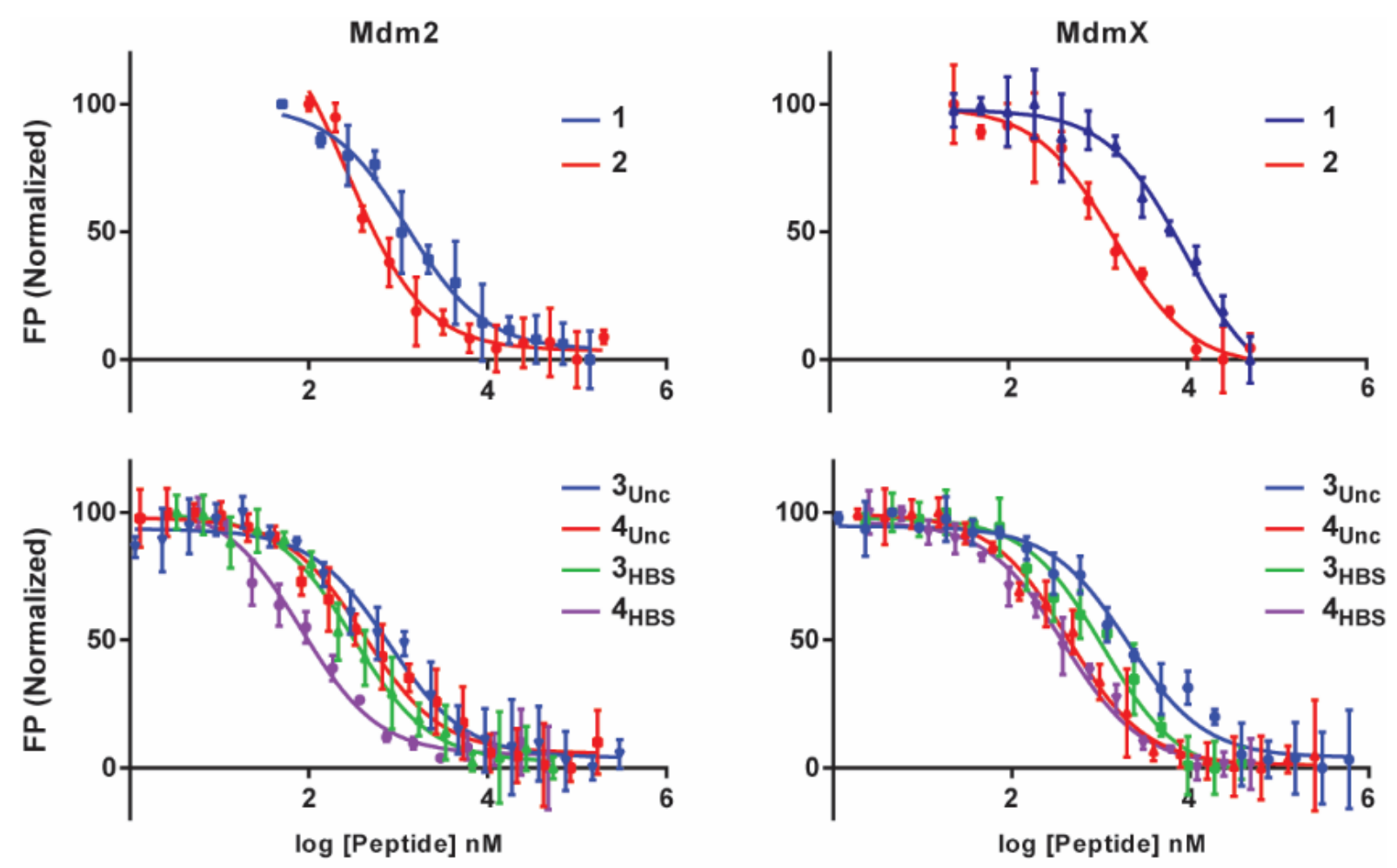

\begin{tabular}{|c|c|c|c|c|c|c|c|c|c|c|c|c|c|c|c|c|c|c|}
\hline Peptide & & 16 & 17 & 18 & 19 & 20 & 21 & 22 & 23 & 24 & 25 & 26 & 27 & 28 & 2930 & $31 \quad 32$ & $\mathrm{~K}_{\mathrm{i}}, \mathrm{Mdm} 2(\mathrm{nM})$ & $\mathrm{K}_{\mathrm{i}}, \operatorname{MdmX}(\mathrm{nM})$ \\
\hline 1 & $A C$ & $Q$ & $\mathrm{E}$ & $\mathrm{T}$ & $\mathrm{F}$ & $\mathrm{s}$ & $D$ & $\mathrm{~L}$ & $w$ & $\mathrm{~K}$ & L & $\mathrm{L}$ & $P$ & $E$ & $\mathrm{~N}$ & & $1049 \pm 476$ & $1420 \pm 425$ \\
\hline 2 & $A c$ & $Q$ & $\mathrm{E}$ & $\mathrm{T}$ & $\mathrm{F}$ & $\mathrm{s}$ & $\mathrm{D}$ & $\mathrm{L}$ & $w$ & $\mathrm{~K}$ & L & $\mathrm{L}$ & $P$ & G & W & & $355 \pm 116$ & $106 \pm 51$ \\
\hline 3 Unc & $A C$ & $Q$ & $\mathrm{E}$ & G & $\mathrm{F}$ & $\mathrm{s}$ & $\mathrm{D}$ & $\mathrm{L}$ & w & $\mathrm{K}$ & $\mathrm{L}$ & $\mathrm{L}$ & $\mathrm{s}$ & & & & $271 \pm 80$ & $205 \pm 61$ \\
\hline 4Unc & $A c$ & Q & $\mathrm{E}$ & G & $\mathrm{F}$ & $\mathrm{s}$ & $\mathrm{D}$ & $\mathrm{L}$ & W & $\mathrm{K}$ & L & L & $\mathrm{s}$ & G & W & & $157 \pm 47$ & $87 \pm 21$ \\
\hline 3 HBS & X & $Q$ & $E$ & $\mathrm{G}^{*}$ & $\mathrm{~F}$ & $\mathrm{~s}$ & $\mathrm{D}$ & $\mathrm{L}$ & W & $\mathrm{K}$ & L & L & $\mathrm{S}$ & & & & $112 \pm 46$ & $123 \pm 34$ \\
\hline 4HBS & $x$ & $Q$ & $\mathrm{E}$ & $\mathrm{G}^{*}$ & $\mathrm{~F}$ & $\mathrm{~s}$ & $D$ & $\mathrm{~L}$ & w & K & $\mathrm{L}$ & $\mathrm{L}$ & $\mathrm{s}$ & G & w & & $4 \pm 8$ & $50 \pm 16$ \\
\hline
\end{tabular}

Figure S4 Competitive fluorescence polarization binding curves with data summarized in table. $\mathrm{X}=4$-pentenoic acid. $\mathrm{G}^{*}=o$-nosyl-N-allylglycine. Line between $\mathrm{X}$ and $\mathrm{G}^{*}$ represents $\mathrm{HBS}$ macrocyclization. All peptides are $\mathrm{C}$ terminally amidated. 


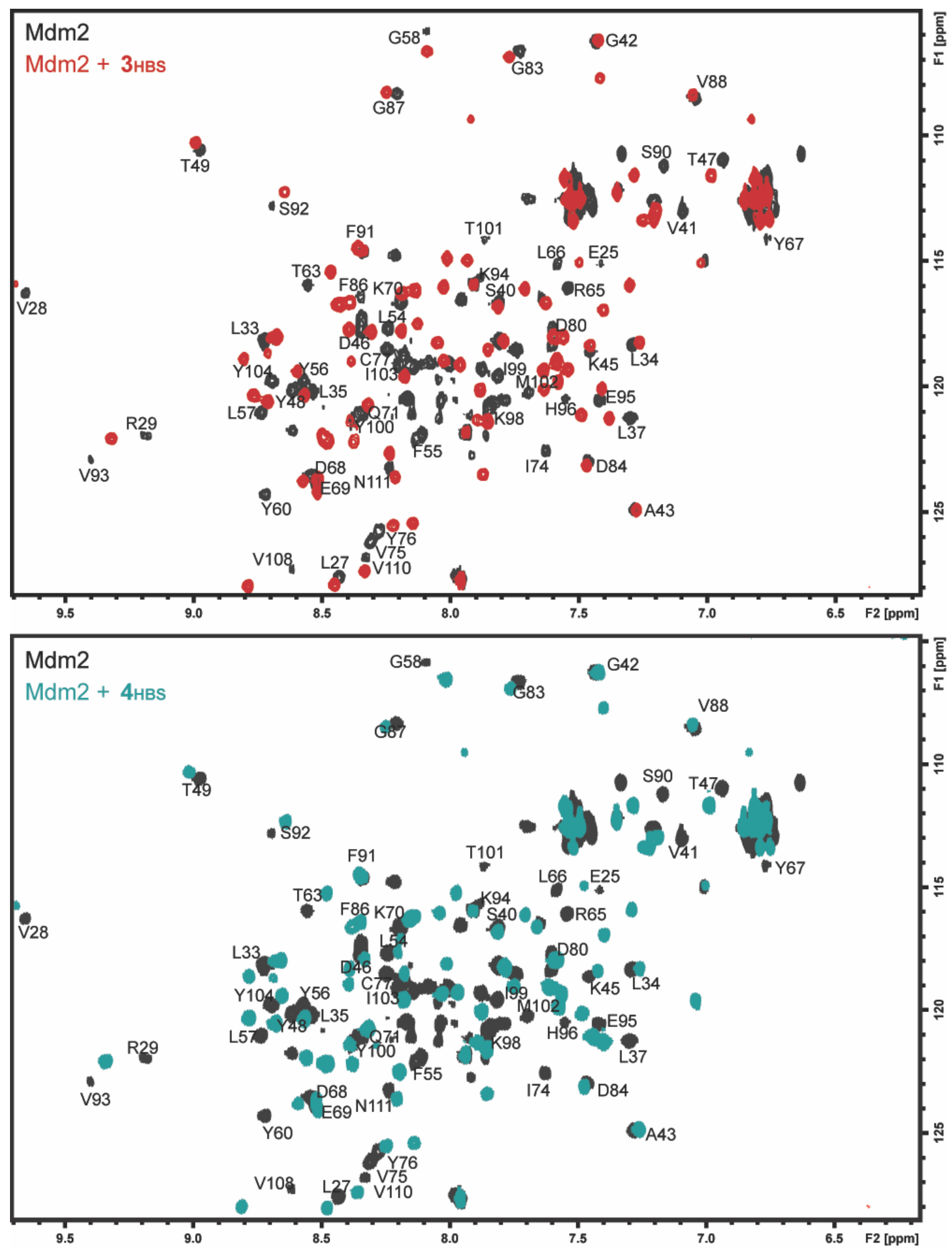

Figure S5 ${ }^{15} \mathrm{~N}-{ }^{1} \mathrm{H}$ HSQC NMR spectra of ${ }^{15} \mathrm{~N}$-labelled Mdm2 apo (black), in complex with $\mathbf{3}_{\mathrm{HBs}}$ (red), and in complex with $\mathbf{4}_{\mathrm{HBS}}$ (teal). 

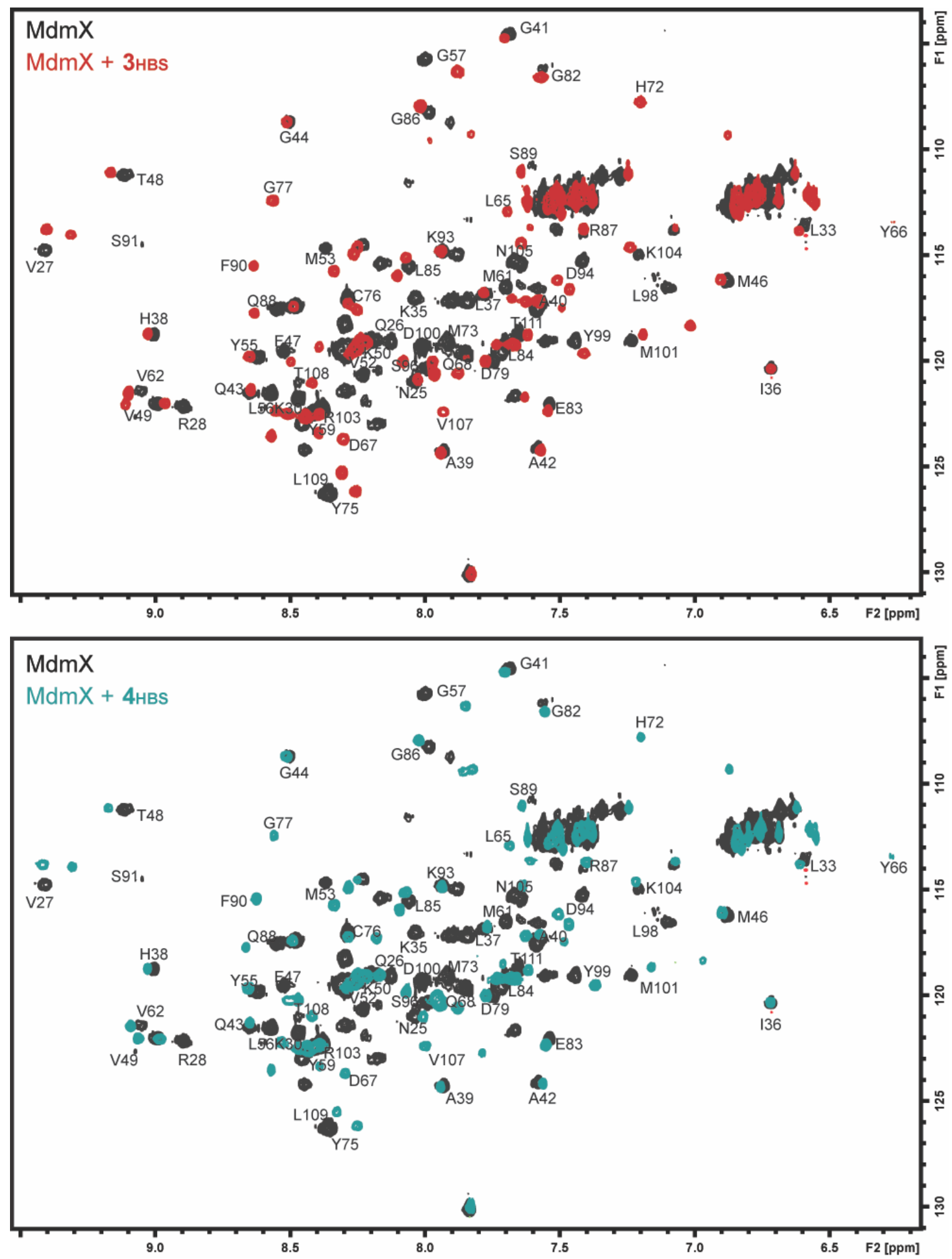

Figure S6 ${ }^{15} \mathrm{~N}-{ }^{1} \mathrm{H}$ HSQC NMR spectra of ${ }^{15} \mathrm{~N}$-labelled MdmX apo (black), in complex with $\mathbf{3}_{\mathrm{HBS}}$ (red), and in complex with $\mathbf{4}_{\mathrm{HBs}}$ (teal). 
M d m $2: 3_{\text {HBS }}$

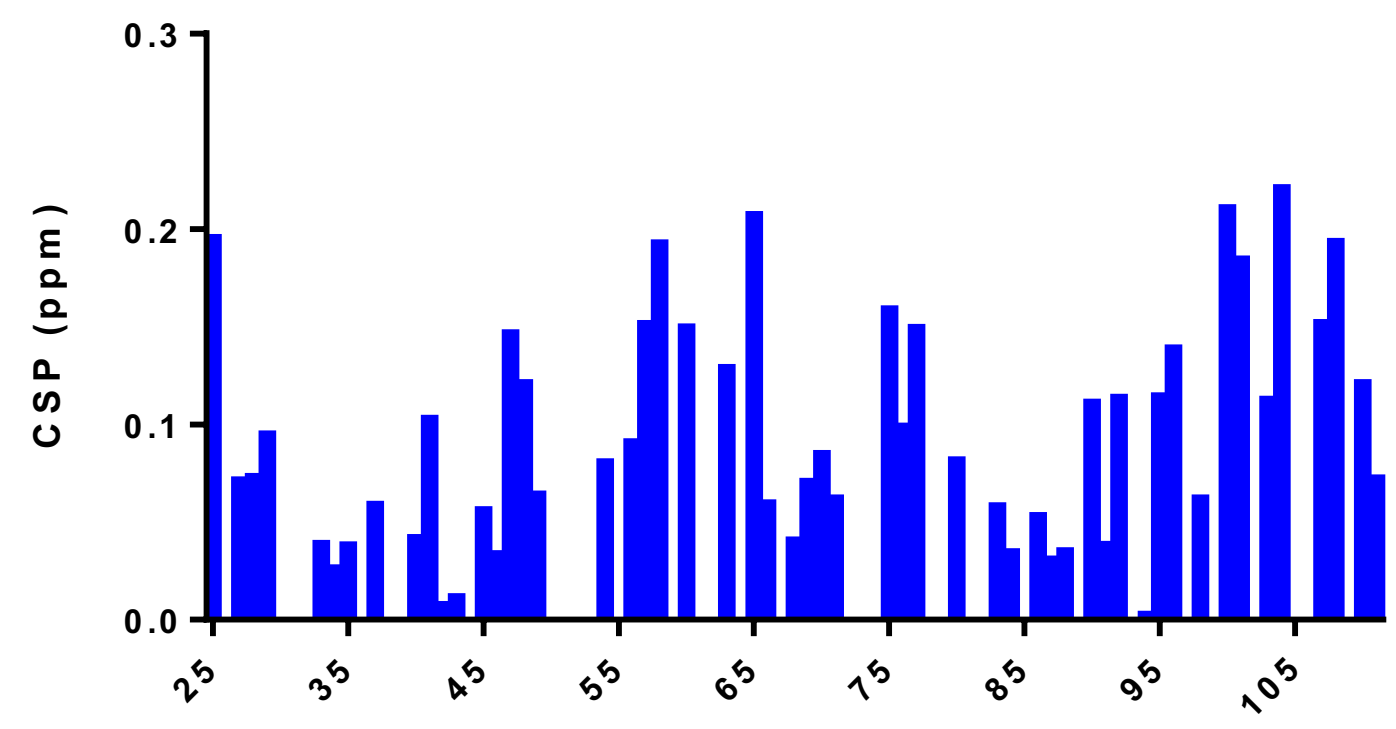

Residue \#

Figure $\mathbf{S} 7{ }^{15} \mathrm{~N}-{ }^{1} \mathrm{H}$ HSQC NMR chemical shift perturbations of Mdm2 upon addition of $\mathbf{3}_{\mathrm{HBS}}$

M d m $2: 4_{\text {H B S }}$

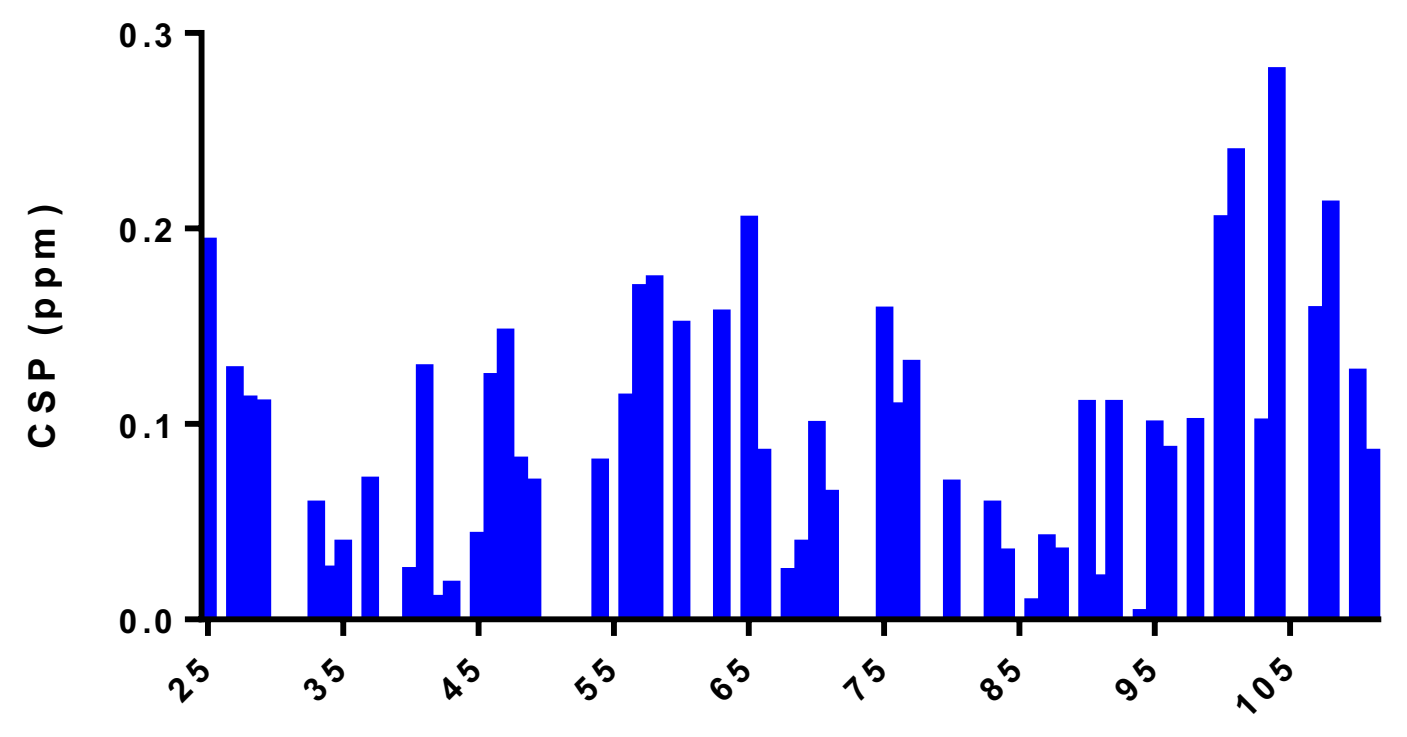

Residue \#

Figure $\mathbf{S 8}{ }^{15} \mathrm{~N}-{ }^{1} \mathrm{H}$ HSQC NMR chemical shift perturbations of Mdm2 upon addition of $\mathbf{4}_{\mathrm{HBS}}$ 
M d m X: $3_{\text {нв }}$

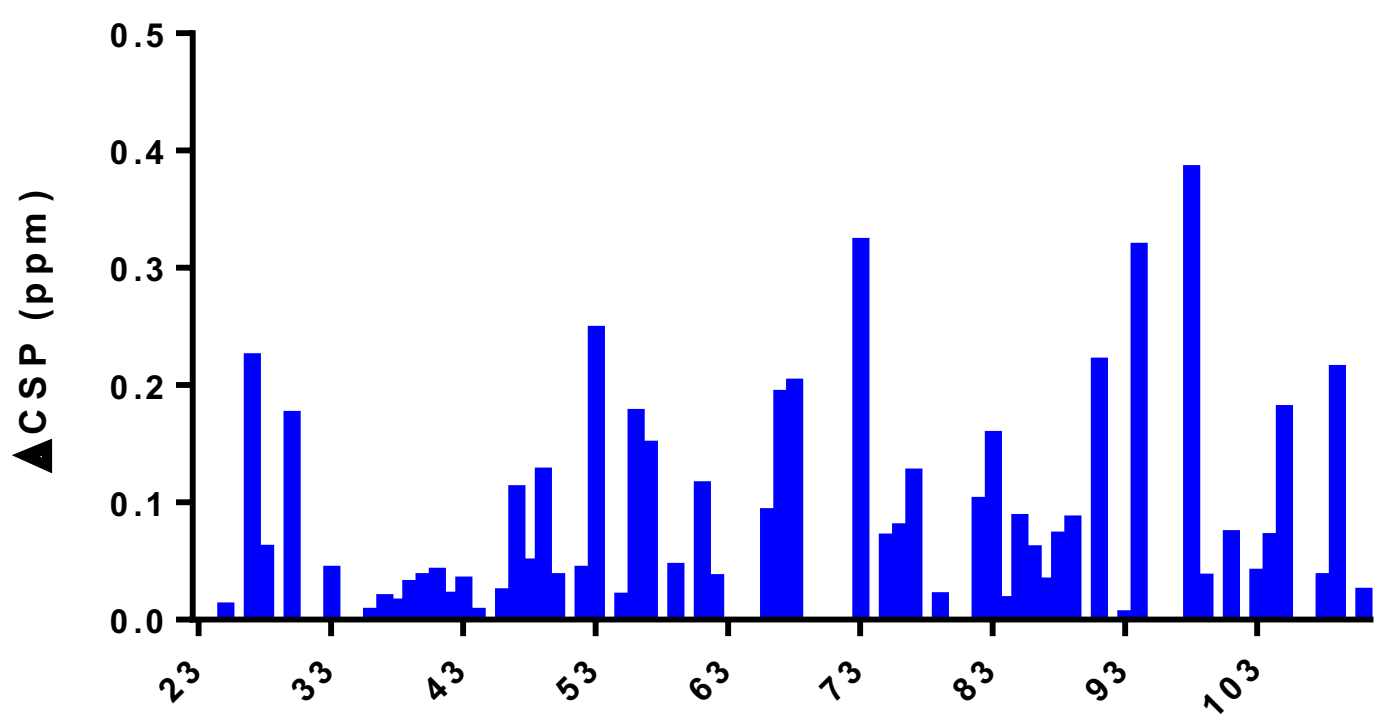

Residue \#

Figure S9 ${ }^{15} \mathrm{~N}-{ }^{1} \mathrm{H}$ HSQC NMR chemical shift perturbations of MdmX upon addition of $\mathbf{3}_{\mathrm{HBS}}$

\section{M d m X:4 нв}

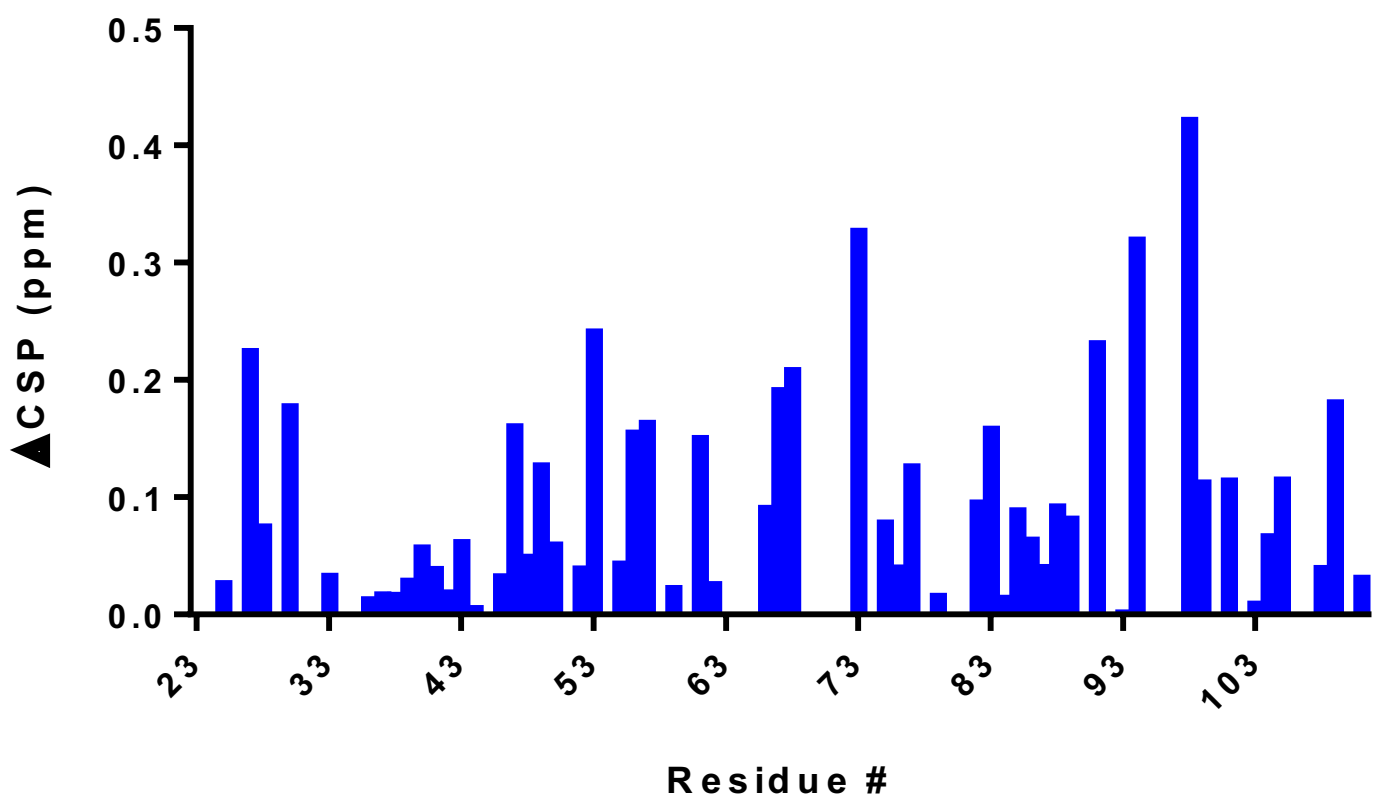

Figure $510{ }^{15} \mathrm{~N}-{ }^{-1} \mathrm{H}$ HSQC NMR chemical shift perturbations of MdmX upon addition of $\mathbf{4}_{\mathrm{HBS}}$ 


\section{Supporting Methods}

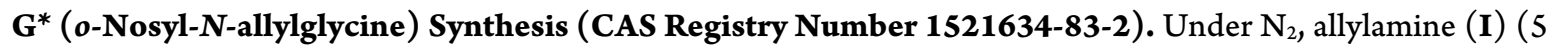
mmol, $374 \mu \mathrm{L})$ was dissolved in $7 \mathrm{~mL}$ DCM with triethylamine $(5 \mathrm{mmol}, 697 \mu \mathrm{L})$ on ice. $o$-nitrobenzenesulfonyl chloride ( $4.5 \mathrm{mmol}, 1008 \mathrm{mg}$ ) was dissolved in $3 \mathrm{~mL}$ DCM and slowly added to the former solution. The mixture was brought to room temp and monitored by TLC ( $25 \% \mathrm{EtOAc} /$ hexane). After $1.5 \mathrm{hr}$ when $o$-NBS-Cl was consumed, the reaction was quenched with $10 \mathrm{~mL} 1 \mathrm{M} \mathrm{HCl}$ (aq). The DCM layer was collected and the aqueous layer with was rinsed with $3 \mathrm{x}$ DCM. Organic layers were combined and concentrated in vacuo. The resulting yellow oil was dissolved in $10 \mathrm{~mL}$ EtOAc and rinsed $3 \mathrm{x}$ with brine. The organic layer was dried with $\mathrm{Na}_{2} \mathrm{SO}_{4}$, filtered, and concentrated in vacuo to afford Ns-allylamine (II) as a white solid in $93 \%$ yield.

Ns-allylamine (II) $(15.9 \mathrm{mmol})$ and tert-butyl bromoacetate $(20.7 \mathrm{mmol}, 3052 \mu \mathrm{L})$ were dissolved in $50 \mathrm{~mL}$ DMF and stirred at room temp. To this solution was added $\mathrm{K}_{2} \mathrm{CO}_{3}(33.4 \mathrm{mmol}, 4615 \mathrm{mg})$ portion-wise and the reaction was allowed to proceed overnight. Upon completion as determined by TLC ( $25 \% \mathrm{EtOAc/hexane),} \mathrm{the} \mathrm{reaction} \mathrm{was}$ quenched with ethanolamine $(25 \mathrm{mmol}, 2460 \mu \mathrm{L})$ and stirred for $1 \mathrm{hr}$. The mixture was diluted with $100 \mathrm{~mL} \mathrm{Et}_{2} \mathrm{O}$ and washed with $3 \times 1 \mathrm{M} \mathrm{HCl}, 3 \mathrm{x}$ sat. $\mathrm{NaHCO}_{3}$, and $3 \mathrm{x}$ brine. The organic later was dried over $\mathrm{Na}_{2} \mathrm{SO}_{4}$, filtered, and concentrated in vacuo to afford III in quantitative yield.

Compound III (2.9 mmol, $1.05 \mathrm{~g}$ ) was dissolved in $20 \mathrm{~mL}$ of TFA/DCM (50:50) and stirred at room temperature for two hours until loss of starting material by TLC (25\% EtOAc/hexane, drop of $\mathrm{NEt}_{3}$ ). Product was concentrated in vacuo and recrystallized from EtOAc/hexane to afford $\mathbf{G}^{*}$ as a white solid in quantitative yield.

o-Nosyl- $\mathbf{N}$-allylglycine [CAS Registry Number 1521634-83-2]. ESI-MS [M+Na] ${ }^{+}$Calc: 323.03 , Obs: $323.0 ;{ }^{1} \mathrm{H}$ $\operatorname{NMR}\left(500 \mathrm{MHz}, \mathrm{CD}_{3} \mathrm{CN}\right) \delta 7.99(\mathrm{dd}, 1 \mathrm{H}), 7.67(\mathrm{~m}, 3 \mathrm{H}), 5.64(\mathrm{~m}, 1 \mathrm{H}), 5.12(\mathrm{~m}, 2 \mathrm{H}), 4.00(\mathrm{~s}, 2 \mathrm{H}), 3.92(\mathrm{~d}, \mathrm{~J}=6$ $\mathrm{Hz}, 2 \mathrm{H}) ;{ }^{13} \mathrm{C}$ NMR $\left(400 \mathrm{MHz}, \mathrm{CD}_{3} \mathrm{CN}\right) \delta 170.1,148.7,135.1,133.5,133.1,133.0,131.4,125.0,120.1,51.6,47.8$

Peptide (1, 2, 3Unc, $4_{\text {Unc }}$ ) Synthesis. Peptides were synthesized by Fmoc SPPS on Rink Amide resin. Resin was thoroughly rinsed with DMF and DCM between steps. Fmoc deprotection was done with $20 \%$ piperidine in DMF with $0.1 \mathrm{M} \mathrm{HOBt}(2 \times 10 \mathrm{~min})$. Amino acid coupling was performed by pre-activation of Fmoc-AA-OH with DIC and $\mathrm{HOBt}$ ( 5 eq. each with respect to resin, $10 \mathrm{~min}$ activation, $45 \mathrm{~min}$ coupling). $\mathrm{N}$-termini were acetylated with 5 eq. each of $\mathrm{Ac}_{2} \mathrm{O}$ and DIEA for $10 \mathrm{~min}$. Cleavage from resin and global deprotection was done with $95 \% \mathrm{TFA}, 2.5 \%$ triisopropylsilane, $2.5 \%$ water for two hours. Resin beads were removed by filtration and solvent was removed in vacuo. Solid peptide was obtained by trituration with cold diethyl ether followed by centrifugation and ether decantation. Peptides were purified by RP-HPLC on a C18 column running a gradient of $15-60 \% \mathrm{MeCN}$ in water with $0.1 \%$ TFA followed by lyophilization.

HBS Peptide ( $3_{\mathrm{HBs}}, 4_{\mathrm{HBs}}$ ) Synthesis. Peptides were synthesized by Fmoc SPPS on Rink Amide resin according to procedure reported by Miller et al. ${ }^{1}$ Resin was thoroughly rinsed with DMF and DCM between steps. Fmoc deprotection was done with $20 \%$ piperidine in DMF with $0.1 \mathrm{M} \mathrm{HOBt}(2 \times 10 \mathrm{~min})$. Amino acid coupling was performed by pre-activation of Fmoc-AA-OH with DIC and HOBt (5 eq. each with respect to resin, $10 \mathrm{~min}$ activation, 45 min coupling). $\mathbf{G}^{*}$ and the following E were coupled with HOAt instead of HOBt. Deprotection of nosyl was achieved with 10 eq. each of thiophenol and DIEA in DMF ( 4 x $45 \mathrm{~min})$. N-termini were acylated with 5 eq. each of 4-pentenoic acid and DIC in DMF. Peptides on resin were then thoroughly dried by washing with $\mathrm{Et}_{2} \mathrm{O}$, transferred to microwave tube, and placed under vacuum. To the resin was added $20 \mathrm{~mol} \%$ Hoveyda-Grubbs II (Aldrich) and flushed with $\mathrm{N}_{2} .3 \mathrm{~mL}$ dry 1,2-dichloroethane was added and the mixture was mixed under $\mathrm{N}_{2}$ for 30 min. The tube was placed in a CEM Discover microwave device and subjected to $150 \mathrm{~W}$ and $120^{\circ} \mathrm{C}$ with a 2 min ramp up and $15 \mathrm{~min}$ hold time. Cleavage from resin and global deprotection was done with $95 \%$ TFA, $2.5 \%$ triisopropylsilane, $2.5 \%$ water for two hours. Resin beads were removed by filtration and solvent was removed in vacuo. Solid peptide was obtained by trituration with cold diethyl ether followed by centrifugation and ether decantation. Peptides were purified by RP-HPLC on a C18 column running a gradient of $15-60 \% \mathrm{MeCN}$ in water with $0.1 \%$ TFA followed by lyophilization. 
FAM-P4 Fluorescent Probe Synthesis. Peptide was synthesized by Fmoc SPPS on Wang resin to afford a Cterminal acid as described above and reported by Czarna et al. ${ }^{2}$ The $\mathrm{N}$-terminus was capped with 5'caroxyfluorescein (HOBt/DIC). Cleavage and purification were carried out as described above.

Protein Expression and Purification. A pET-14b vector coding for Mdm2 (25-117) with a 6xHis tag was obtained as a generous gift from the lab of Neal Zondlo. A pET-28b vector coding for MdmX (23-111) with a 6xHis tag was used for MdmX expression. Mdm2 expression was performed with $100 \mu \mathrm{g} / \mathrm{mL}$ ampicillin and MdmX expression was performed with $50 \mu \mathrm{g} / \mathrm{mL}$ kanamycin (both are referred to as "antibiotic" in the following). Plasmids were transformed into BL21(DE3) competent cells. One colony was inoculated in $5 \mathrm{~mL}$ LB with antibiotic overnight which was transferred to $1 \mathrm{~L} \mathrm{LB}$ with antibiotic and shaken at $37^{\circ} \mathrm{C}$ until an $\mathrm{OD}_{600}$ of 0.6 . Expression was induced with $0.5 \mathrm{mM}$ IPTG and the culture was shaken at room temperature for $6 \mathrm{hr}$. In the case of ${ }^{15} \mathrm{~N}$-labelled protein, LB was replaced with M9 minimal media supplemented with ${ }^{15} \mathrm{NH}_{4} \mathrm{Cl}$. Cells were pelleted by centrifugation and stored at $-80^{\circ} \mathrm{C}$. Buffers used for purification contained $20 \mathrm{mM}$ tris- $\mathrm{HCl} \mathrm{pH} \mathrm{7.9,1} \mathrm{M} \mathrm{NaCl}$, and $5 \mathrm{mM} \beta$-mercaptoethanol. Cells were resuspended in $30 \mathrm{~mL}$ buffer with $5 \mathrm{mM}$ imidazole, $10 \mathrm{mg}$ lysozyme, $1 \mathrm{mM}$ PMSF, $1 \mathrm{mM}$ benzamidine, 1 $\mu \mathrm{g} / \mathrm{mL}$ pepstatin $\mathrm{A}$, and $1 \mu \mathrm{g} / \mathrm{mL}$ leupeptin. After the cells were sonicated on ice, lysate was collected by centrifugation and incubated with $1 \mathrm{~mL}$ pre-equilibrated Ni-NTA resin (Thermo) at $4{ }^{\circ} \mathrm{C}$ with gentle rocking for 30 min. Flow-through was collected and the resin was washed with buffer containing $20 \mathrm{mM}$ imidazole. The resin was then treated with buffer fractions containing 60 to $300 \mathrm{mM}$ imidazole for elution. Pure fractions identified by SDSPAGE were pooled and dialyzed with a 3.5k MWCO slide-a-lyzer cassette (Thermo) in 1x PBS pH 7.4, 5 mM EDTA, $0.5 \mathrm{mM}$ DTT, and $10 \%$ glycerol and stored flash-frozen in $10-20 \mu \mathrm{M}$ aliquots at $-80^{\circ} \mathrm{C}$.

Fluorescence Polarization (FP) Binding Assay. Binding affinities for peptide-protein interactions were determined with fluorescence polarization based on the method reported by Lao et al. ${ }^{3} \mathrm{FP}$ assays were performed in $1 \times$ PBS pH 7.4, $5 \mathrm{mM}$ EDTA, $0.5 \mathrm{mM}$ DTT, and 0.1\% pluronic acid (Aldrich) on a DTX 880 Multimode Detector (Beckman) at $25^{\circ} \mathrm{C}$, with $485 \mathrm{~nm}$ excitation and $525 \mathrm{~nm}$ emission. Protein was spin-concentrated with $3.5 \mathrm{k} \mathrm{MWCO}$ centrifugal filter (Millipore Sigma) before experiments and direct binding with $\mathbf{P 4}$ was always performed the day off competition experiments. Probe P4 was held constant at $15 \mathrm{nM}$ with protein titrated over 0 to $3.8 \mu \mathrm{M}(\mathrm{Mdm} 2)$ and $9.5 \mu \mathrm{M}(\mathrm{MdmX})$ Binding affinities reported are averages of three experiments and fitted to nonlinear regression sigmoidal dose-response model of GraphPad Prism 5.0.

$\mathrm{K}_{\mathrm{D} 1}=\left[\mathrm{R}_{\mathrm{T}} \mathbf{x}\left(1-\mathrm{F}_{\mathrm{SB}}\right)+\mathrm{L}_{\mathrm{ST}} \times \mathrm{F}_{\mathrm{SB}}^{2}\right] / \mathrm{F}_{\mathrm{SB}}-\mathrm{L}_{\mathrm{ST}}$

$\mathrm{R}_{\mathrm{T}}=[$ protein $]$

$\mathrm{L}_{\mathrm{ST}}=[$ fluorescent probe $]$

$\mathrm{F}_{\mathrm{SB}}=$ fraction fluorescent probe bound

The $\mathrm{K}_{\mathrm{D} 1}$ of $\mathbf{P 4}$ was determined to be $11.22 \pm 2 \mathrm{nM}$ and $26.5 \pm 10 \mathrm{nM}$ to $\mathrm{Mdm} 2$ and MdmX, respectively. For competition experiments, wells contained a probe:protein concentration ratios corresponding to 0.7 fraction bound in the direct binding experiment. Peptide of interest was then titrated over 0 to $100 \mu \mathrm{M}$ and the 96 -well plate was agitated for $30 \mathrm{~min}$. Peptide binding affinities, $\mathrm{K}_{\mathrm{D} 2}$, were determined according to loss of fluorescence polarization from dissociation of probe-protein.

$$
\begin{aligned}
& \mathrm{K}_{\mathrm{D} 2}=\mathrm{K}_{\mathrm{D} 1} \times \mathrm{F}_{\mathrm{SB}} \times\left[\left(\mathrm{L}_{\mathrm{T}} /\left(\mathrm{L}_{\mathrm{ST}} \times \mathrm{F}_{\mathrm{SB}}-\left(\mathrm{K}_{\mathrm{D} 1}+\mathrm{L}_{\mathrm{ST}}+\mathrm{R}_{\mathrm{T}}\right) \times \mathrm{F}_{\mathrm{SB}}+\mathrm{R}_{\mathrm{T}}\right)\right)-1 /\left(1-\mathrm{F}_{\mathrm{SB}}\right)\right] \\
& \mathrm{K}_{\mathrm{D} 1}=\mathrm{K}_{\mathrm{D}} \text { of probe-protein } \\
& \mathrm{R}_{\mathrm{T}}=[\text { protein }] \\
& \mathrm{L}_{\mathrm{ST}}=[\text { fluorescent probe }] \\
& \mathrm{F}_{\mathrm{SB}}=\text { fraction peptide bound at } \mathrm{EC}_{50} \\
& \mathrm{~L}_{\mathrm{T}}=[\text { peptide }]
\end{aligned}
$$


${ }^{1} \mathbf{H}-{ }^{15} \mathbf{N}$ HSQC NMR Spectroscopy. ${ }^{15} \mathrm{~N}$-labelled Mdm2 and MdmX were concentrated to 50 and $90 \mu \mathrm{M}$, respectively, in NMR buffer $\left(25 \mathrm{mM}\right.$ tris- $\mathrm{HCl} \mathrm{pH} 7.4,150 \mathrm{mM} \mathrm{NaCl}, 0.1 \mathrm{mM}$ EDTA, $0.02 \% \mathrm{NaN}_{3}, 2 \mathrm{mM} \mathrm{DTT}$, $10 \% \mathrm{D}_{2} \mathrm{O}$ ) using a 3.5k MWCO centrifugal filter (Millipore Sigma). HSQC spectra were collected on a $600 \mathrm{MHz}$ Bruker four-channel NMR at $298 \mathrm{~K}$. Protein residue resonances were assigned as previously reported for Mdm2 $2^{4,5}$ and MdmX. ${ }^{6,7}$ In separate experiments, HBS peptides $\mathbf{3}_{\mathrm{HBs}}$ and $\mathbf{4}_{\mathrm{HBs}}$ were titrated into solution with $\mathrm{Mdm} 2$ ( $0.5 \mathrm{eq}$ peptide) and MdmX ( 1 eq peptide) and the differences were analyzed. Chemical shift perturbations were determined as previously described. ${ }^{8}$

$$
\Delta \delta=\sqrt{0.5 \times\left(\delta_{H}^{2}+0.1 \delta_{N}^{2}\right)}
$$

CD Spectroscopy. Peptides $\mathbf{4}_{\mathrm{Unc}}$ and $\mathbf{4}_{\mathrm{HBs}}$ were dissolved at $50 \mu \mathrm{M}$ in $50 \mathrm{mM}$ sodium phosphate $\mathrm{pH}$ 7.4. Spectra were collected on a Jasco J-1500 CD Spectrometer as an average of 5 accumulations with scanning speed of 50 $\mathrm{nm} / \mathrm{min}$ and digital integration time of $4 \mathrm{sec}$. Blank values were subtracted and data was normalized to mean residue ellipticity.

AlphaSpace Analysis and Fragment Screening. MDM protein structures are downloaded RCSB Protein Data Bank $(\mathrm{PDB})^{9}$ including $28 \mathrm{PDB}$ files for Mdm2 and $20 \mathrm{PDB}$ files for MdmX. Pocket mapping and comparison is performed using AlphaSpace 2.0 following the proposed protocol. ${ }^{10}$ The structures are aligned, and in each structure $\beta$ atoms are detected by AlphaSpace 2.0. All detected $\beta$ atoms are clustered into ensemble pockets using average linkage ${ }^{11}$ and $\beta$ atoms in each structure are relabeled by the ensemble pocket ID. Pocket spaces and BScores are calculated using AlphaSpace 2.0. In order to constrain fragments in the pocket or pocket community of interest, detected $\beta$ atoms are used to define the searching space of the docking algorithm, and a $2 \AA$ buffer space was added on each searching dimension. Smina, ${ }^{12}$ a fork of Autodock Vina, ${ }^{13}$ is used to conduct fragment screening and the 20 amino acid side chains are used as the fragment library. Glycine and proline are not included in our analysis since the former does not have a side chain and the latter has its side chain fused with the backbone, which makes it hard to isolate the binding energy contribution of the side chain atoms and have a fair comparison with other amino acid side chains. 


\section{Supporting References}

[1] Miller, S. E., Thomson, P. F., and Arora, P. S. (2014) Synthesis of Hydrogen-Bond Surrogate $\alpha$-Helices as Inhibitors of Protein-Protein Interactions, Curr. Protoc. Chem. Biol. 6, 101-116.

[2] Czarna, A., Popowicz, G. M., Pecak, A., Wolf, S., Dubin, G., and Holak, T. A. (2009) High affinity interaction of the p53 peptide-analogue with human Mdm2 and Mdmx, Cell Cycle 8, 1176-1184.

[3] Lao, B. B., Drew, K., Guarracino, D. A., Brewer, T. F., Heindel, D. W., Bonneau, R., and Arora, P. S. (2014) Rational Design of Topographical Helix Mimics as Potent Inhibitors of Protein-Protein Interactions, J. Am. Chem. Soc. 136, 7877-7888.

[4] Stoll, R., Renner, C., Mühlhahn, P., Hansen, S., Schumacher, R., Hesse, F., Kaluza, B., Engh, R. A., Voelter, W., and Holak, T. A. (2000) Letter to the Editor: Sequence-specific 1H, 15N, and 13C assignment of the Nterminal domain of the human oncoprotein MDM2 that binds to p53, J. Biomol. NMR 17, 91-92.

[5] Uhrinova, S., Uhrin, D., Powers, H., Watt, K., Zheleva, D., Fischer, P., McInnes, C., and Barlow, P. N. (2005) Structure of Free MDM2 N-terminal Domain Reveals Conformational Adjustments that Accompany p53binding, J. Mol. Biol. 350, 587-598.

[6] Chen, R., Zhou, J., Qin, L., Chen, Y., Huang, Y., Liu, H., and Su, Z. (2017) A Fusion Protein of the p53 Transaction Domain and the p53-Binding Domain of the Oncoprotein MdmX as an Efficient System for High-Throughput Screening of MdmX Inhibitors, Biochemistry 56, 3273-3282.

[7] Sanchez, M. C., Renshaw, J. G., Davies, G., Barlow, P. N., and Vogtherr, M. (2010) MDM4 binds ligands via a mechanism in which disordered regions become structured, FEBS Lett. 584, 3035-3041.

[8] Williamson, M. P. (2013) Using chemical shift perturbation to characterise ligand binding, Prog. Nucl. Magn. Reson. Spect. 73, 1-16.

[9] Berman, H. M., Westbrook, J., Feng, Z., Gilliland, G., Bhat, T. N., Weissig, H., Shindyalov, I. N., and Bourne, P. E. (2000) The Protein Data Bank, Nucleic Acids Res. 28, 235-242.

[10] Katigbak, J., Li, H., Rooklin, D., and Zhang, Y. (2020) AlphaSpace 2.0: Representing Concave Biomolecular Surfaces Using $\beta$-Clusters, J. Chem. Inf. Model 60, 1494-1508.

[11] Sokal, R. R., Michener, C. D., and Kansas, U. o. (1958) A Statistical Method for Evaluating Systematic Relationships, University of Kansas.

[12] Koes, D. R., Baumgartner, M. P., and Camacho, C. J. (2013) Lessons Learned in Empirical Scoring with smina from the CSAR 2011 Benchmarking Exercise, J. Chem. Inf. Model 53, 1893-1904.

[13] Trott, O., and Olson, A. J. (2010) AutoDock Vina: Improving the speed and accuracy of docking with a new scoring function, efficient optimization, and multithreading, J. Comp. Chem. 31, 455-461. 